\title{
Synaptic Activity Reduces Intraneuronal A $\beta$, Promotes APP Transport to Synapses, and Protects against A $\beta$-Related Synaptic Alterations
}

\author{
Davide Tampellini, ${ }^{1}$ Nawreen Rahman, ${ }^{1}$ Eduardo F. Gallo, ${ }^{1}$ Zhenyong Huang, ${ }^{1}$ Magali Dumont, ${ }^{1}$ \\ Estibaliz Capetillo-Zarate, ${ }^{1}$ Tao Ma, ${ }^{1}$ Rong Zheng, ${ }^{2}$ Bao Lu, ${ }^{3}$ David M. Nanus, ${ }^{2}$ Michael T. Lin, ${ }^{1}$ and Gunnar K. Gouras ${ }^{1,4}$ \\ Departments of ${ }^{1}$ Neurology and Neuroscience and ${ }^{2}$ Medicine, Weill Medical College of Cornell University, New York, New York 10065, ${ }^{3}$ Pulmonary \\ Division, Children’s Hospital, Harvard Medical School, Boston, Massachusetts 02115, and ${ }^{4}$ Rockefeller University, New York, New York 10065
}

A central question in Alzheimer's disease research is what role synaptic activity plays in the disease process. Synaptic activity has been shown to induce $\beta$-amyloid peptide release into the extracellular space, and extracellular $\beta$-amyloid has been shown to be toxic to synapses. We now provide evidence that the well established synaptotoxicity of extracellular $\beta$-amyloid requires $\gamma$-secretase processing of amyloid precursor protein. Recent evidence supports an important role for intraneuronal $\beta$-amyloid in the pathogenesis of Alzheimer's disease. We show that synaptic activity reduces intraneuronal $\beta$-amyloid and protects against $\beta$-amyloid-related synaptic alterations. We demonstrate that synaptic activity promotes the transport of the amyloid precursor protein to synapses using live cell imaging, and that the protease neprilysin is involved in reduction of intraneuronal $\beta$-amyloid with synaptic activity.

\section{Introduction}

$\beta$-Amyloid $(\mathrm{A} \beta)$ accumulation in the brain is a hallmark of Alzheimer's disease (AD) pathology (Haass and Selkoe, 2007). A $\beta$ has been shown to target synapses (Lacor et al., 2004; Deshpande et al., 2009), and synaptic damage is the best pathologic correlate of cognitive decline in AD (DeKosky and Scheff, 1990; Terry et al., 1991; Selkoe, 2002). Remarkably, in vitro and in vivo studies demonstrated that synaptic stimulation induces secretion of $\mathrm{A} \beta$ into the extracellular space (Kamenetz et al., 2003; Cirrito et al., 2005, 2008). However the effect of synaptic activity on the cell biology of amyloid precursor protein (APP) and A $\beta$ and the role of synaptic activity in $\mathrm{AD}$ pathogenesis remain poorly understood.

Accumulation and aggregation of $\mathrm{A} \beta$ both intracellularly and extracellularly have been associated with neuritic and synaptic pathology (Takahashi et al., 2002; Meyer-Luehmann et al., 2008), and with reductions in synaptic plasticity and levels of synaptic proteins in several models (Selkoe, 2002; Coleman and Yao, 2003; Almeida et al., 2005; Hsieh et al., 2006; Palop et al., 2006; Shankar et al., 2008). The relationship between the intracellular and ex-

Received May 14, 2009; revised June 19, 2009; accepted June 28, 2009.

This work was supported by an Alzheimer's Association New Investigator Award (D.T.) and Zenith Award (G.K.G.) the Appel Foundation, and National Institute of Health Grants AG20729 (M.T.L.), AG027140, AG028174, and AG09464 (G.K.G.). We thank Dr. Carlos Dotti, Catholic University of Leuven, for providing the APP-YFP construct, Dr. Karen H. Ashe, University of Minnesota, for generating the Tg2576 mice, and Dr. George Carlson, McLaughlin Research Institute, for providing the Tg19959 mice. We appreciate the input from the Trafficking Group seminars organized by the Weill Cornell Department of Biochemistry. We thank Dr. Costantino ladecola in our Division of Neurobiology for advice on the barrel cortex experiments.

The authors declare no competing financial interests.

Correspondence should be addressed to Gunnar K. Gouras, Department of Neurology and Neuroscience, Weill Cornell Medical College, 525 East 68th Street, New York, NY 10065. E-mail: gkgouras@med.cornell.edu. DOI:10.1523/JNEUROSCI.2292-09.2009

Copyright $\odot 2009$ Society for Neuroscience $\quad$ 0270-6474/09/299704-10\$15.00/0 tracellular pools of $A \beta$ is complex (Oddo et al., 2006). Intraneuronal accumulation of $\mathrm{A} \beta$ precedes the appearance of plaques (Oddo et al., 2003), and when $A \beta$ is removed by immunotherapy, the intracellular pool reemerges first (Oddo et al., 2004). On the other hand, extracellular $\mathrm{A} \beta$ can induce the accumulation of intracellular $A \beta$ (Yang et al., 1999). We now provide evidence that the effects of extracellular $A \beta$ on synapses require $\gamma$-cleavage processing of APP, which generates new intracellular $\mathrm{A} \beta$.

Since intracellular accumulation of $\mathrm{A} \beta$ has been associated with physiological dysfunction (Oddo et al., 2003), cognitive decline (Billings et al., 2005; Knobloch et al., 2007), ultrastructural synaptic pathology (Takahashi et al., 2002, 2004), and neurotoxicity (Kienlen-Campard et al., 2002; Zhang et al., 2002; Casas et al., 2004; Magrané et al., 2005), understanding how synaptic activity modulates intraneuronal $\mathrm{A} \beta$ could be critical in better understanding the pathogenesis of $\mathrm{AD}$. We now show that synaptic activation reduces levels of intraneuronal $\mathrm{A} \beta$ and protects against $\mathrm{A} \beta$-related synaptic changes. We also demonstrate that synaptic activity promotes APP transport to synapses and that the $\mathrm{A} \beta$ degrading protease neprilysin is involved in the activity-induced reduction of intraneuronal $\mathrm{A} \beta 42$.

\section{Materials and Methods}

cDNA constructs. Human APP-yellow fluorescent protein (YFP) construct was a gift from Dr. Carlos Dotti (Catholic University of Leuven, Leuven, Belgium) (Kaether et al., 2000). Neurons were transfected overnight using Lipofectamine 2000 (Invitrogen).

Antibodies. 6E10 (Signet): human specific A $\beta / A P P / \beta C T F s ; 4 G 8$ (Signet): A $\beta$ /APP; P2-1 (BioReagents): human specific APP $N$ terminus; 22C11 (Millipore Bioscience Research Reagents): APP N terminus; 12F4 (Covance): A $\beta 42 \mathrm{C}$ terminus; PSD-95 (Millipore Bioscience Research Reagents); GM130 (BD Transduction Laboratories); synapsin I (Sigma); synaptophysin (Millipore Bioscience Research Reagents); 
NR1 (Upstate); tubulin (Sigma); phospho-CaMKII (Millipore Bioscience Research Reagents); total CaMKII (Millipore Bioscience Research Reagents); $\mathrm{A} \beta 42$ (Millipore Bioscience Research Reagents): A $\beta 42 \mathrm{C}$ terminus.

Acute hippocampal slice preparation. Hippocampal slices were prepared from 2-months-old Tg19959 mice (Li et al., 2004). Mice were deeply anesthetized with isoflurane and decapitated. The brain was rapidly removed and placed in ice-cold artificial CSF (ACSF) containing (in mм) $118 \mathrm{NaCl}, 3.5 \mathrm{KCl}, 2.5 \mathrm{CaCl}_{2}, 1.3 \mathrm{MgSO}_{4}, 1.25 \mathrm{NaH}_{2} \mathrm{PO}_{4}, 24$ $\mathrm{NaHCO}_{3}$, and 15 glucose, bubbled with $95 \% \mathrm{O}_{2} / 5 \% \mathrm{CO}_{2}$. The hippocampus was then quickly dissected out, and $400-\mu \mathrm{m}$-thick transverse slices were made on a tissue chopper in a cold room $\left(4^{\circ} \mathrm{C}\right)$. The slices were maintained in an interface chamber (ACSF and humidified 95\% $\mathrm{O}_{2} / 5 \%$ $\mathrm{CO}_{2}$ atmosphere) at room temperature for at least $2 \mathrm{~h}$ before removal for drug treatment. Drug incubation was performed at room temperature in submersion maintenance chambers containing ACSF saturated with bubbling $95 \% \mathrm{O}_{2} / 5 \% \mathrm{CO}_{2} . \mathrm{KCl}$ was prepared as stock solutions and diluted to final concentrations in ACSF before use. Hippocampal slices were incubated for $8 \mathrm{~h}$ with $35 \mathrm{~mm} \mathrm{KCl}$ or vehicle and collected. Slices were snap frozen in liquid nitrogen for quantification of $\mathrm{A} \beta$ by ELISA or fixed with $4 \%$ paraformaldehyde (PFA) for A $\beta 42$ immunofluorescence.

Surgical procedure for unilateral removal of whiskers. At 2 months of age, Tg19959 mice were anesthetized with an intraperitoneal injection of ketamine and xylazine and placed on a heated pad. Mice received a small dose of local anesthetic, via subcutaneous injection of bupivicaine in the portion of the snout that underwent surgery. Mouse snouts were shaved (whiskers and fur) unilaterally and disinfected with 70\% ethanol and then betadine. An incision was made with a scalpel around the skin area $(\sim 3 \times 5 \mathrm{~mm})$ containing the whisker follicles, which were then removed. The area was cleaned by washing with sterile saline solution and the wound was sutured with vicryl stitches. At 4 months of age, mice were killed with pentobarbital and perfused with $4 \%$ PFA. Brains were removed and incubated at $4^{\circ} \mathrm{C}$ in increasing percentages of sucrose $(10,20$ and $30 \%)$. Brains were then cut with a cryostat and stained for COX (Wong-Riley and Welt, 1980) or A $\beta 42$ immunofluorescence (Takahashi et al., 2008). The contralateral barrel cortices (corresponding to the half snouts that did not undergo surgery) were used as controls.

Cell culture and treatments. Primary neuronal cultures from Tg2576 mice (Hsiao et al., 1996) and wild-type littermates were prepared as described (Tampellini et al., 2007). Primary neurons were used at 8-10 d in vitro (DIV) for live imaging and metabolic labeling, and at 12 DIV for all other experiments. Human A $\beta 1-42$ (Tocris) was prepared in MilliQ water as described (Snyder et al., 2005). The $\gamma$-secretase inhibitor $N$ - $[N$ (3,5-difluorophenacetyl-1-alanyl)]-S-phenylglycine $t$-butyl ester (DAPT; Calbiochem) was diluted in culture medium to $250 \mathrm{nM}$. Neurons were treated with DAPT for a total of $2 \mathrm{~h}$; after $1 \mathrm{~h}$ in DAPT, neurons were additionally incubated in the presence or absence of $1 \mu \mathrm{M} \mathrm{A} \beta 1-42$. Neprilysin inhibitor thiorphan (Sigma) was diluted in culture medium to 50 $\mu \mathrm{M}$. Neurons were treated with thiorphan during the $75 \mathrm{~min}$ long-term potentiation (LTP) protocol.

Treatment for synaptic activity. Primary neurons were incubated $8 \mathrm{~h}$ with $35 \mathrm{~mm} \mathrm{KCl}$ and collected. For chemical-LTP, neurons were treated for $1 \mathrm{~h}$ with $1 \mu \mathrm{M}$ tetrodotoxin (TTX; Tocris) to reduce endogenous synaptic activity and to prevent phosphorylation of proteins involved in synaptic activation (Ehlers, 2003). After TTX incubation, neurons were washed once with LTP buffer containing $140 \mathrm{~mm} \mathrm{NaCl}, 1.3$ $\mathrm{mm} \mathrm{CaCl}_{2}, 10 \mathrm{~mm} \mathrm{KCl}, 25$ mм HEPES, 33 mм glucose, $0.5 \mu \mathrm{M}$ TTX, $1 \mu \mathrm{M}$ strychnine, and $20 \mu \mathrm{M}$ bicuculline (Lu et al., 2001; Ehlers, 2003) and then incubated for $15 \mathrm{~min}$ in LTP buffer with or without $200 \mu \mathrm{M}$ glycine. Glycine is an NMDA receptor coactivator acting in concert with glutamate. Because glutamate release occurs only at synapses, the NMDA receptors activated by glycine are only those present at synapses and not those at extra-synaptic sites. Together with the stochastic quantal release of glutamate at synapses, glycine coactivation of NMDA receptors at synapses leads to LTP. It is known that binding of glycine to its receptors induces hyperpolarization with a consequent inhibitory action on neurons, but the buffer used to induce g-LTP contains strychnine $(1 \mu \mathrm{M})$, which prevents activation of inhibitory glycine receptors. After $15 \mathrm{~min}$, neurons were chased for $1 \mathrm{~h}$ in fresh LTP solution without glycine and then collected.

$A \beta$ detection. Primary neurons were washed twice, harvested in icecold PBS, and centrifuged. Pellets were lysed with $6 \%$ SDS containing 10 $\mu \mathrm{l} / \mathrm{ml} \beta$-mercaptoethanol, sonicated, and then heated at $95^{\circ} \mathrm{C}$ for $6 \mathrm{~min}$. After centrifugation, supernatants were loaded directly into $10-20 \%$ Tricine gels (Invitrogen). Samples were subjected to electrophoresis and transferred to polyvinylidine difluoride membranes (Millipore). Membranes were boiled in PBS for $5 \mathrm{~min}$ and immunoblotted. The reaction was visualized by chemiluminescence (Pierce). Band intensities were quantified using Scion Image software.

ELISA analysis. Tg2576 primary neurons were plated in $6 \mathrm{~cm}$ dishes and collected. Concentrations of $\mathrm{A} \beta 1-40$ and $\mathrm{A} \beta 1-42$ were measured by using the respective ELISA kits (Biosource). ELISA values are given in picograms per milliliter since the same amount of total protein was used from equivalent neuron cultures.

Synaptosomal preparation. Synaptosomes were purified as described (Ehlers, 2003; Almeida et al., 2005). Briefly, pellets from collected neurons were homogenized in a buffer containing $0.32 \mathrm{M}$ sucrose and $4 \mathrm{~mm}$ HEPES pH 7.4 (buffer 1). Homogenates were centrifuged at $1000 \times g$ for $10 \mathrm{~min}$. The pellet (P1), containing heavy organelles, including nuclei, Golgim and endoplasmic reticulum, was kept for qualitative analysis. Supernatants were transferred to clean tubes and centrifuged at 10,000 $\times$ $g$ for 15 min to pellet the crude synaptosomal pellet (P2). P2s were resuspended in buffer 1 and centrifuged at $10,000 \times g$ for 15 min. Pellets containing washed P2 were then lysed and processed as described for biochemical measurements of surface proteins.

Biochemical measurements of surface proteins. Primary neurons were washed twice with $\mathrm{PBS}$ containing $1 \mathrm{~mm} \mathrm{CaCl}_{2}$ and $0.5 \mathrm{~mm}$ $\mathrm{MgCl}_{2}$ (PBS-Ca-Mg), placed on ice to block endocytosis, and incubated with PBS-Ca-Mg containing $1 \mathrm{mg} / \mathrm{ml}$ Sulfo-NHS-LC-Biotin (Pierce) for $15 \mathrm{~min}$. Cultures were rinsed in ice-cold culture medium to quench the biotin reaction and lysed in $200 \mu \mathrm{l}$ of $2 \%$ SDS. The homogenates were centrifuged at $14,000 \times \mathrm{g}$ for $15 \mathrm{~min}$ at $4^{\circ} \mathrm{C}$. Fifteen microliters of the supernatant were removed to measure total protein levels; the remaining supernatant was incubated with $100 \mu \mathrm{l}$ of Neutravidin agarose (Pierce) overnight at $4^{\circ} \mathrm{C}$. Samples were then washed three times with a buffer containing: $150 \mathrm{~mm} \mathrm{NaCl}, 10 \mathrm{~mm}$ Tris $\mathrm{HCl}, \mathrm{pH}$ 8.3, 5 mm EDTA, $0.1 \%$ Triton X-100, $0.01 \%$ BSA and protease inhibitor cocktail (Roche). Bound proteins were resuspended in $30 \mu \mathrm{l}$ of SDS sample buffer and boiled. Quantitative Western blots were performed on both total and biotinylated (surface) proteins using APP N-terminal antibody $22 \mathrm{C} 11$ or NR1 antibody. Immunoreactive bands were visualized by enhanced chemiluminescence (ECL, Amersham) and captured on autoradiography film (Amersham Hyperfilm ECL). Scanned images were quantified using Scion Image software. The surface/total APP and NR1 ratios were calculated for each culture.

Immunofluorescence. Neurons were grown on poly-D-lysine coated coverslips (Thermo Fisher Scientific). Neurons were washed in icecold PBS and fixed for immunofluorescence (Tampellini et al., 2007). Alexa-488 or Alexa-546 fluorescent secondary antibodies were used (Invitrogen). Neurons were viewed either with an Olympus Optical IX-70 microscope equipped with an ORCA-ER charge-coupled device camera (Hamamatsu Photonics) and a 60×, 1.4 numerical aperture (NA) plan apochromat objective or a confocal microscope (TCS SP5, Leica) equipped with $\mathrm{HeNe} 633 \mathrm{~nm} / \mathrm{HeNe} 543 \mathrm{~nm} /$ Argon (458, 476, 488, 514 $\mathrm{nm}$ ) imaging lasers, a 5-Channel Leica "SP" Spectral Fluorescence Detection laser scanning unit, and a HCX PLAPO CS $63 \times / 1.4-0.6$ oil objective (optical sections were acquired at $0.5 \mu \mathrm{m}$ thickness, or $0.7 \mu \mathrm{m}$ for hippocampal slices). MetaMorph software 7.5 (Universal Imaging) was used for quantitative analysis. To quantify $\mathrm{A} \beta$ immunofluorescence, 5-10 neurons were randomly picked from each independent experiment, and average intensities were measured in selected areas. Intensity threshold was set to remove background fluorescence. Total fluorescence per 30 $\mu \mathrm{m}$ of a thresholded neurite was automatically quantified. To quantify $\mathrm{A} \beta$ immunofluorescence in hippocampal slices and brain, total fluorescence per field was measured using MetaMorph on thresholded images collected by confocal microscope; three images per stack were used for each section. Averages of measurements per section per mouse were 
considered as an individual measurement. For quantification of PSD-95 puncta, one or two coverslips from each culture were analyzed, 5-10 neurons per coverslip. From each neuron, $3-5$ neurite segments $30 \mu \mathrm{m}$ in length were selected from areas where single puncta could be outlined. Images were thresholded so that only the brightest puncta, with intensity at least twice that of the neuritic shaft, were outlined. Using the integrated morphometric analysis feature in MetaMorph, puncta density was automatically measured. Localization of APP to synapses labeled by synapsin I in confocal acquired images was determined by using a colocalization algorithm (Leica Application Suite 1.8.2 software), which shows only pixels with relative colocalization. Threshold was set at $65 \%$ for both fluorophores.

To localize surface APP to synapses labeled by synapsin I, neurons fixed in $4 \%$ paraformaldehyde were first stained for APP with P2-1 antibody and corresponding fluorescent secondary antibody without permeabilization. Once surface APP staining was completed, we permeabilized neurons with $0.1 \%$ saponin and incubated for $1 \mathrm{~h}$ with synapsin I antibody and then $1 \mathrm{~h}$ with fluorescent secondary antibody at $37^{\circ} \mathrm{C}$.

To visualize only intraneuronal $\mathrm{A} \beta 42$ immunofluorescence (Runz et al., 2002; Almeida et al., 2006) in wild-type neurons and eliminate the fluorescence coming from the added synthetic $A \beta 1-42$ that attached to the cell surface, we quenched the A $\beta 42$ surface signal as follows. After fixation in $4 \%$ paraformaldehyde, and in absence of permeabilization, neurons were incubated with $12 \mathrm{~F} 4$ (mouse) A $\beta 42$ specific antibody, followed by incubation with a nonfluorescent anti-mouse secondary antibody (quenching). Neurons were washed, permeabilized with saponin, and then stained by using the Millipore Bioscience Research Reagents (rabbit) A $\beta 42$ specific antibody, followed by incubation with a fluorescent anti-rabbit secondary antibody to prevent recognition of possible surface unquenched 12F4 (mouse) antibody. Images were acquired with the Olympus microscope and a $60 \times, 1.4$ NA plan apochromat objective.

Live-cell imaging. Neurons were grown on poly-D-lysine coated glass bottom microwell dishes (MatTek Corporation). Neurons were transfected with human APP-YFP overnight and then imaged in $37^{\circ} \mathrm{C}$ LTP solution at steady state or during activation with glycine. In some live imaging experiments, glycine was infused during imaging. Neurons were imaged in a $37^{\circ} \mathrm{C}$ chamber using an Olympus Optical IX-70 microscope and a $60 \times, 1.4$ NA plan apochromat objective. Frames were automatically and sequentially acquired every $10 \mathrm{~s}$ with a specific YFP filter using MetaMorph; " $n$ " refers to the number of independent cultures transfected with APP-YFP. One or two coverslips from each culture were analyzed (1-2 neurons per coverslip). For each neuron, 1-2 dendritic segments $30 \mu \mathrm{m}$ long were selected from areas where single fluorescent vesicles could be outlined. In glycine infusion experiments, we analyzed segments between 100 and $160 \mu \mathrm{m}$ long. Preparation of kymographs and kymographic analyses were performed using MetaMorph. We counted the total number of vesicles detected in one neurite (100\%) and then quantified the percentage of vesicles that were stationary, moving anterogradely, or moving retrogradely.

Metabolic labeling. Primary neurons were plated in $10 \mathrm{~cm}$ dishes. After $30 \mathrm{~min}$ in cysteine/methionine-free medium (Invitrogen), neurons were pulsed in fresh cysteine/methionine-free medium containing $1 \mathrm{mCi}$ $\left[{ }^{35} \mathrm{~S}\right]$ methionine/cysteine (Perkin-Elmer) for $30 \mathrm{~min}$. Neurons were then chased in LTP buffer for $15 \mathrm{~min}$ in the presence or absence of $200 \mu \mathrm{M}$ glycine and then chased again for $1 \mathrm{~h}$ in glycine-free LTP buffer. Media were centrifuged for $10 \mathrm{~min}$ and transferred to clean tubes, and neurons were collected in ice-cold PBS and lysed. Samples were immunoprecipitated with $A \beta$ antibody $4 \mathrm{G} 8 .\left[{ }^{35} \mathrm{~S}\right]$ signal was visualized using a phosphoimager system (Hewlett-Packard Cyclone).

Statistical analysis. Statistical comparisons were made using two-tailed unpaired $t$ tests with significance placed at $p<0.05$. A set of cultures prepared from one mouse embryo was considered as one independent experiment $(n=1)$. Data were expressed as mean \pm SEM. Statistical analysis was performed using Excel and GraphPad Prism 3.0 (Graph Pad Software).

\section{Results}

\section{Synaptic activation reduces intraneuronal $\mathrm{A} \beta$ and protects} against $\mathrm{A} \boldsymbol{\beta}$-related synaptic alterations

Stimulation of cultured primary neurons from APP Swedish mutant transgenic (Tg2576) mice was performed using a well estab- lished glycine-induced LTP (g-LTP) protocol (Lu et al., 2001; Ehlers, 2003; Wang et al., 2008). This protocol uses glycine as coactivator of NMDA receptors together with glutamate, while blocking inhibitory glycine receptors with strychnine. Activation of neurons by g-LTP caused a $38 \pm 11 \%$ decrease in levels of intraneuronal $\mathrm{A} \beta$ (Fig. 1 $a$, third panel from top). Induction of LTP was confirmed by demonstrating elevation in phosphorylated-CaMKII but not total CaMKII in g-LTP stimulated neurons (Figs. $1 a, 4 g, h$ ). In agreement with the Western blot data, ELISA revealed a reduction in levels of both $A \beta 1-40$ and A $\beta 1-42$ peptides in glycine-treated Tg2576 neurons (Fig. $1 b$ ). Confirming these biochemical results, there was a $39 \pm 4 \%$ reduction in intraneuronal $\mathrm{A} \beta 42$ immunofluorescence in dendrites after g-LTP as seen by confocal microscopy (Fig. 1c). Using $\mathrm{KCl}$-induced depolarization as an alternative activation protocol similarly reduced levels of intraneuronal $\mathrm{A} \beta$ by $39 \pm 9 \%$ (supplemental Fig. S1, available at www.jneurosci.org as supplemental material). To verify that the effect of synaptic activation on intraneuronal $\mathrm{A} \beta$ is not confined to dissociated primary neurons, we used acute hippocampal slices prepared from APP transgenic mice (Tg19959). KCl-induced depolarization reduced levels of intraneuronal $A \beta 42$ by $13 \pm 2 \%$ in CA1 neuronal soma as shown by confocal immunofluorescence (Fig. $2 a$ ). ELISA confirmed the $\mathrm{KCl}$-induced decrease of $\mathrm{A} \beta 42$ in hippocampal slices (Fig. $2 b$ ) and a nonstatistically significant trend of decrease for $A \beta 40$ (Fig. $2 b)(p=0.09)$. We also examined the effect of synaptic activity on intraneuronal $\mathrm{A} \beta$ in vivo, by chronic inhibition of somatosensory cortex. The barrel cortex of Tg19959 mice was deafferented by irreversible unilateral removal of whisker bulbs at 2 months of age. Mice were killed at 4 months of age, and cytochrome oxidase (COX) staining in the deafferented barrel cortex was markedly reduced compared with the nondeafferented side, reflecting reduced neuronal activity (Fig. 2c) (Wong-Riley and Welt, 1980). Compared with the control side, barrel cortex with reduced activity revealed a $10 \pm 1 \%$ increase in $\mathrm{A} \beta 42$ immunofluorescence in neuronal soma (Fig. 2d). We next used metabolic labeling to examine the effects of synaptic activity on newly generated $A \beta$ in cultured neurons. Levels of newly generated intraneuronal $\mathrm{A} \beta$ were decreased $43 \pm 11 \%$ by g-LTP (Fig. $2 e$, third panel from top), and there was the expected increase $(44 \pm 15 \%)$ in levels of newly generated secreted $\mathrm{A} \beta(\mathrm{sA} \beta)$ (Fig. $2 e$, bottom panel). Consistent with previous evidence (Kamenetz et al., 2003), g-LTP led to an increase in levels of $\beta$-cleaved APP C-terminal fragments ( $\beta$ CTFs; $93 \pm 41 \%$ for steady state, Fig. $1 a$, second panel from top; $22 \pm 8 \%$ for newly generated; Fig. $2 e$, second panel from top), but there was no statistically significant change in levels of full-length APP (Fig. 1a, supplemental Fig. S2, available at www. jneurosci.org as supplemental material, for steady state; Fig. $2 e$ for newly generated) or $\alpha$ CTFs (data not shown).

Previous studies suggest that both extracellular $A \beta$ and intracellular $\mathrm{A} \beta$ might be synaptotoxic. Thus, one would expect increased extracellular $A \beta$ to be toxic, but decreased intracellular A $\beta$ to be beneficial. Since synaptic activity both increased extracellular $\mathrm{A} \beta$ and decreased intracellular $\mathrm{A} \beta$, it was not clear what the effect on synaptic proteins would be. We therefore investigated levels of the postsynaptic scaffold protein PSD-95, which are reduced in Tg2576 neurons (Almeida et al., 2005; Tampellini et al., 2007). g-LTP led to a $35 \pm 10 \%$ increase in the number of PSD-95 puncta in Tg2576 neurons, which also showed reduced A $\beta 42$ immunofluorescence compared with control (Fig. 1d). In particular, induction of g-LTP restored puncta of PSD-95 in Tg2576 neurons to wild-type levels (supplemental Fig. S3, available at www.jneurosci.org as supplemental material). In contrast, 


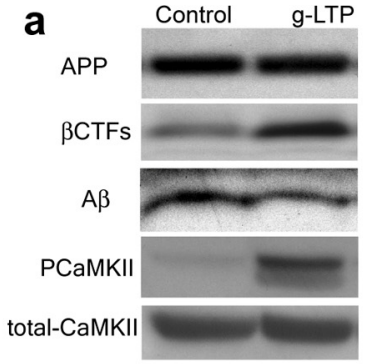

C

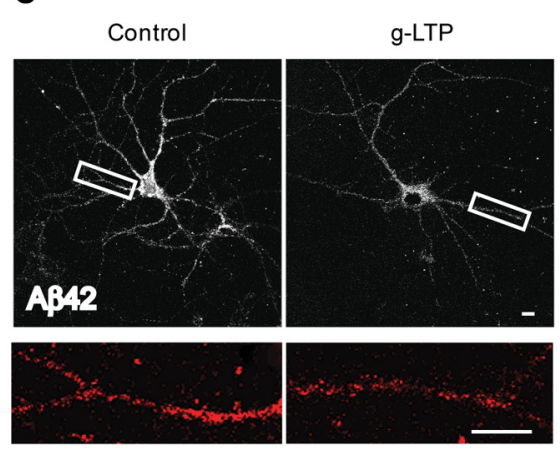

d
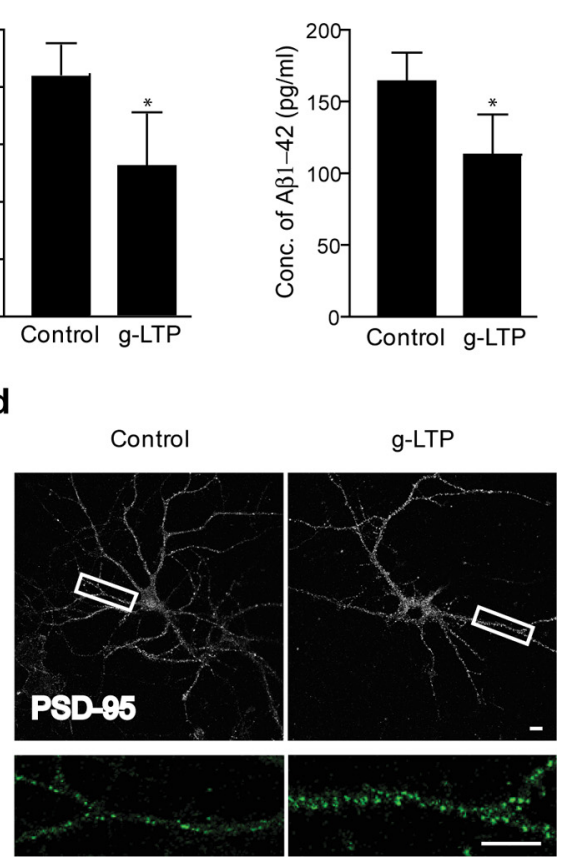

A $\beta 1-42$ to the media in the absence of DAPT, were unaltered when $\mathrm{A} \beta 1-42$ was added in the presence of DAPT (Fig. $3 a, c, d, e$ ). To further confirm that the observed synaptic alterations induced by extracellular $\mathrm{A} \beta 1-42$ occur via APP and generation of $\mathrm{A} \beta$, we repeated the previous experiments in neurons cultured from APP knock-out mouse (APP KO) embryos. When treated with $1 \mu \mathrm{m} \mathrm{A} \beta 1-42$, APP KO neurons did not reveal a decrease in PSD-95 puncta, but rather showed similar levels of PSD-95 to untreated APP KO neurons or APP KO neurons treated with both $\mathrm{A} \beta 1-42$ and DAPT (Fig. 3f). Overall, these data support that extracellular $A \beta 1-42$-induced synaptic alterations require amyloidogenic processing of APP.

\section{Synaptic activity promotes transport of} APP to synapses

To explore the mechanisms whereby synaptic activity leads to increased $A \beta$ secretion and reduced intracellular $A \beta$, we investigated the effects of synaptic activation on processes affecting $\mathrm{A} \beta$ generation, including APP trafficking, surface localization, and cleavage processing, and also explored the role of $\mathrm{A} \beta$ degradation.

We first analyzed APP trafficking by live cell imaging after synaptic activation in neurons transfected with YFP-tagged human APP (APP-YFP). Remarkably, there was no change in PSD-95 levels with g-LTP in wild-type neurons (supplemental Fig. S3, available at www.jneurosci.org as supplemental material). These results suggest that in the setting of synaptic activity, the protective effects of reducing intraneuronal $\mathrm{A} \beta$ are more important than the potentially toxic effects of increased extracellular $\mathrm{A} \beta$.

\section{Alterations of synaptic proteins from extracellular A $\beta 1-42$ occur via $\gamma$-secretase processing of APP}

Interestingly, previous work raised the possibility that the toxicity of extracellular A $\beta$ may be mediated via APP processing (Lorenzo et al., 2000; Shaked et al., 2006) and thereby possibly intracellular $\mathrm{A} \beta$, since addition of extracellular $\mathrm{A} \beta 1-42$ increased levels of newly synthesized A $\beta 42$ in cultured cells (Yang et al., 1999). We confirmed the latter also in our experimental model by adding 1 $\mu \mathrm{M} \mathrm{A} \beta 1-42$ to wild-type cultured neurons as previously described (Almeida et al., 2005; Snyder et al., 2005), which revealed a $51 \pm 10 \%$ increase in levels of intraneuronal $A \beta 42$ immunofluorescence in dendrites in treated compared with untreated neurons (Fig. $3 a$, upper panels, $b$ ). We then tested whether extracellular A $\beta 1-42$ would alter levels of specific synaptic proteins when APP $\gamma$-secretase processing and thereby also accumulation of intraneuronal $\mathrm{A} \beta$ was blocked. We again treated wild-type neurons with $1 \mu \mathrm{M}$ extracellular $\mathrm{A} \beta 1-42$, but now in the absence or presence of the $\gamma$-secretase inhibitor DAPT. Levels of intraneuronal $A \beta 42$ did not change compared with control when $\mathrm{A} \beta 1-42$ was added in the presence of DAPT (Fig. $3 a$, upper panels, $b$ ). Remarkably, levels of PSD-95 immunofluorescence and surface glutamate NMDA receptor subunit NR1, which were reduced by $48 \pm 5 \%$ and $40 \pm 2 \%$, respectively, by addition of
g-LTP promoted anterograde transport of APP in dendrites (Fig. $4 a, c$; supplemental Movies S1, steady state, S2, g-LTP, available at www.jneurosci.org as supplemental material). Specifically, there was a fourfold increase in APP-containing vesicles moving anterogradely in dendritic segments with g-LTP (Fig. 4b,d). Furthermore, direct infusion of glycine during live cell imaging of APP-YFP containing vesicles induced a rapid conversion to anterograde transport in dendrites (Fig. 4e; supplemental Movie S3, available at www.jneurosci.org as supplemental material). Vesicles previously moving retrogradely were seen abruptly changing course after stimulation. The g-LTP-induced increase of anterograde APP trafficking resulted in increased APP transport to synapses as shown by a relative increase in APP and synapsin I colocalization by confocal microscopy (Fig. 4f). The APP immunofluorescence in Figure $4 f$ supports the biochemical data (Fig. 1a) that the g-LTP-induced increase in APP localization to synapses was not attributable to an overall increase in total APP (supplemental Fig. S2, available at www.jneurosci.org as supplemental material) or synapsin I (supplemental Fig. S4, available at www.jneurosci.org as supplemental material) but rather to APP transport to synapses within neurons.

To gain more insight into the mechanism of synaptic activity induced $\mathrm{A} \beta$ modulation, we next analyzed APP surface localization and cleavage processing in response to synaptic activation. APP is trafficked to the cell surface, and subsequent generation of $\mathrm{A} \beta$ is thought to require endocytosis and cleavage by $\beta$ - and $\gamma$-secretases (Koo and Squazzo, 1994; Rajendran et al., 2008). Using biotin-surface labeling, we found that whole-cell levels of surface-labeled APP increased by $89 \pm 29 \%$ during synaptic ac- 
tivation (Fig. 4g). These biochemical data were confirmed by immunofluorescence, which showed a $54 \pm 13 \%$ increase in levels of surface APP in nonpermeabilized neurons (supplemental Fig. S5, available at www.jneurosci.org as supplemental material). In contrast, levels of surface APP in synaptosomes decreased by $33 \pm$ $2 \%$ with g-LTP (Fig. 4h) and colocalization of surface APP with synapsin I in nonpermeabilized cells did not increase (Fig. 4i). Although the reduced surface levels of APP at synapses appeared at first to contradict the overall increased surface levels of APP in whole cells, it can be reconciled with the scenario that synaptic activation induces transport of APP to synapses and to the plasma membrane, with a subsequent induction of endocytosis of APP specifically at active synapses; see schema summarizing these findings in supplemental Fig. S6, available at www. jneurosci.org as supplemental material. During internalization, APP is likely cleaved by BACE, as supported by the increased levels of $\beta C T F s$ with g-LTP (Figs. $1 a, 2 e)$.

\section{g-LTP induced reduction of} intraneuronal $\mathrm{A} \beta 42$ requires neprilysin To further explore the mechanism of intraneuronal $\mathrm{A} \beta$ reduction during synaptic activity, we analyzed the role of $A \beta$ degradation. Neprilysin is a zinc peptidase that was empirically shown to be the most efficient protease at degrading $\mathrm{A} \beta$ (Iwata et al., 2000). Moreover, its activity was reported to be increased in brains of $\mathrm{AD}$ transgenic mice showing reduced plaque burden after environmental enrichment (Lazarov et al., 2005). To assess whether neprilysin is involved in intraneuronal $\mathrm{A} \beta$ reduction on synaptic activation, we induced g-LTP in the presence or absence of the neprilysin inhibitor thiorphan. Confocal immunofluorescence microscopy showed that inhibition of neprilysin did not prevent reduction of intraneuronal $\mathrm{A} \beta 40$ by g-LTP. In the presence of thiorphan, intraneuronal A $\beta 40$ was reduced by $12 \pm 1 \%$ in g-LTP activated compared with control neurons (Fig. 5a). In contrast, thiorphan treatment prevented g-LTP mediated reduction of intraneuronal A $\beta 42$ (Fig. $5 b)$. We confirmed these immunofluorescence data by ELISA (Fig. $5 c$ ). To further confirm that $\mathrm{A} \beta 42$ degradation during synaptic activation occurs via neprilysin, we induced g-LTP in neurons cultured from neprilysin KO mouse (NEP KO) embryos (Lu et al., 1995). Consistent with the thiorphan treatment experiments, confocal immunofluorescence microscopy demonstrated that, despite the lack of neprilysin, g-LTP induced a $39 \pm 12 \%$ reduction of intraneuronal A $\beta 40$ (Fig. $5 d$, left panels). In contrast, lack of neprilysin prevented the g-LTP mediated reduction of intraneuronal A $\beta 42$ (Fig. $5 d$, right panels). These results support that neprilysin plays an important role

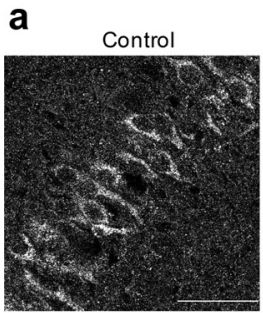

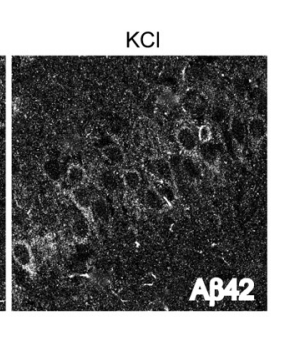
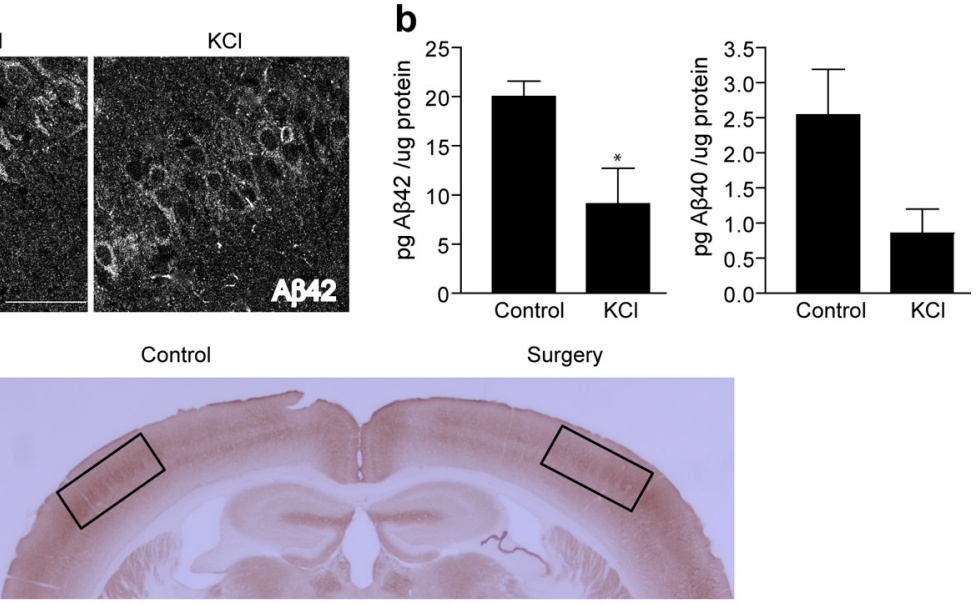

Contro
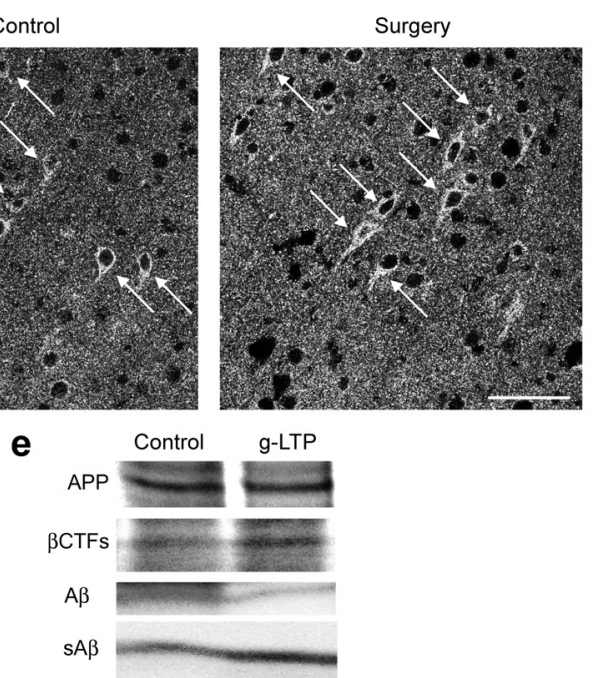

Figure 2. Synaptic activation reduces intraneuronal $A \beta$ in hippocampal slices, whereas chronic inhibition of synaptic activity induces intraneuronal $A \beta$ accumulation in vivo. $\boldsymbol{a}$, Hippocampal slices prepared from $\mathrm{Tg} 19959$ mice and incubated for $8 \mathrm{~h}$ with KCl. Confocal microscopy of $C A 1$ neurons demonstrates $13 \pm 2 \%$ reduction of intraneuronal $A \beta 42$ immunofluorescence in $\mathrm{KCl}$-treated (19959 brain stained for COX. The side corresponding to whisker removal (Surgery) shows a dramatic decrease of COX comwith the control side (Control). $\boldsymbol{d}$, Confocal microscopy showing intraneuronal A $\beta 42$ immunofluorescence of Tg19959 barre 作 作 Levels of newly generated secreted $A \beta(S A \beta)$ (normalized to newly generated APP) were increased by $44 \pm 15 \%$ in media of $g$-LTP activated compared with control Tg2576 neurons $(n=4 ; p<0.05)$. Scale bars, $50 \mu \mathrm{m}$.

in the reduction of $\mathrm{A} \beta 42$, the most disease-linked $\mathrm{A} \beta$ isoform, during synaptic activity.

\section{Discussion}

The role of $\mathrm{A} \beta$ at synapses and the effect of synaptic activity on $\mathrm{A} \beta$ are currently among the most intriguing topics in understanding $\mathrm{AD}$ pathogenesis. In particular, it is of major interest that synaptic activity increases secretion of $A \beta$ into the extracellular space (Kamenetz et al., 2003; Cirrito et al., 2005). On one hand, extracellular A $\beta$ reduces LTP, induces long-term depression, and alters synaptic structure and protein levels in vitro and in vivo (Selkoe, 2002; Coleman and Yao, 2003; Almeida et al., 2005; Snyder et al., 2005; Hsieh et al., 2006; Shankar et al., 2008). Chronic secretion of $\mathrm{A} \beta$ in response to synaptic activity could therefore lead to synaptic damage and accumulation of $\mathrm{A} \beta$ into 


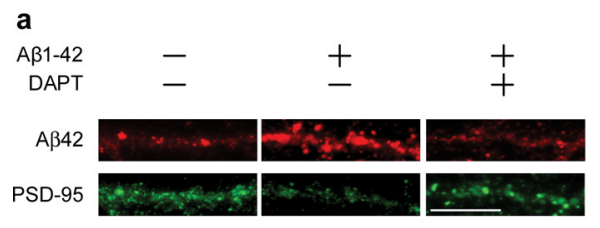

b
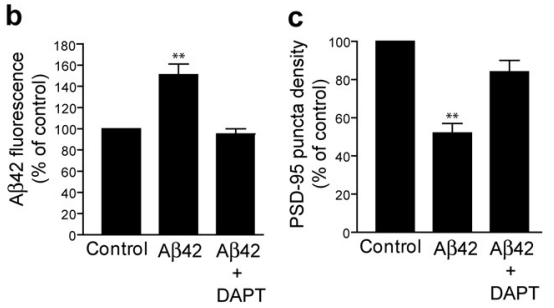

d
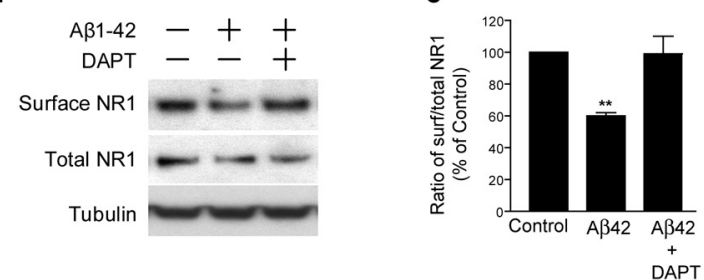

f

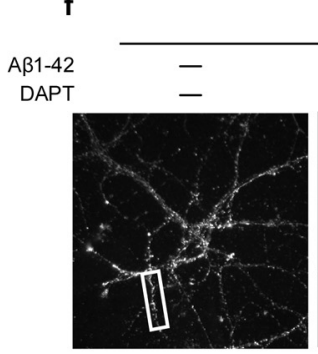

APP KO neurons
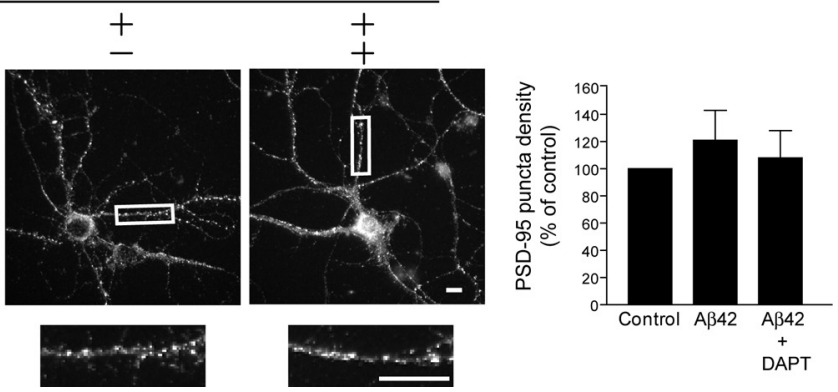

Figure 3. Alterations of synaptic proteins from extracellular A $\beta 1-42$ occur via $\gamma$-secretase processing of APP. $\boldsymbol{a}$, Treatment of wild-type neurons with $A \beta 1-42$ increased levels of intraneuronal A $\beta 42$ and reduced PSD- 95 puncta as evident by immunofluorescence (central panels), but cotreatment with DAPT prevented these effects of A $\beta 1-42$ (right panels). $\boldsymbol{b}$, Quantitation of A $\beta 42$ staining expressed as percentage of the A $\beta 42$ immunofluorescence in the control $(n=5)$. c, Quantitation of PSD-95 expressed as a percentage of PSD-95 immunofluorescence of the control $(n=5)$. $\boldsymbol{d}$, Treatment of wild-type neurons with A $\beta 1-42$ reduced levels of surface NR1 as measured by surface biotinylation followed by Western blot. $e$, Quantitation of the ratio of surface NR1 to total NR1 in A $\beta 1-42$ treated compared with untreated neurons and A $31-42+$ DAPT treated compared with untreated neurons $(n=4) . f$, Treatment of APP KO neurons with A $\beta 1-42$ or A $\beta 1-42+$ DAPT showed unchanged levels of PSD-95 puncta as evident by immunofluorescence. ${ }^{* *} p<0.01$; scale bar: $10 \mu \mathrm{m}$.

plaques, two major hallmarks of $\mathrm{AD}$. Thus, synaptic activity could contribute to the pathogenesis of AD. Indeed, brain regions with high metabolic and synaptic activity are particularly vulnerable to $\mathrm{AD}$ pathology, and $\mathrm{A} \beta$ deposition is increased in epilepsy (Cirrito et al., 2008). Hyperexcitability has been described in AD models and human $\mathrm{AD}$, which could augment synaptic activity-induced $\mathrm{A} \beta$ release and exacerbate pathology (Palop et al., 2007).

On the other hand, there is also evidence that cognitive activity may be protective against AD. Higher educational attainment or participation in intellectually stimulating activities is associated with reduced risk of developing AD (Stern, 2006). Environmental enrichment in APPSwe/PS1 1 E9 mice reduced plaque formation and upregulated genes involved in learning and memory (Lazarov et al., 2005; Ambrée et al., 2006). Although synaptic activity and cognitive activity may not be fully equivalent, it does appear that cognitive activity also increases $\mathrm{A} \beta$ secretion. Recovery of cognitive function after brain injury is associated with increased extracellular $\mathrm{A} \beta$ in human brain (Brody et al., 2008). With potential for both toxicity and benefit, the role of synaptic or cognitive activity in $\mathrm{AD}$ pathogenesis is not clear.

Brain accumulation of $\mathrm{A} \beta$ with $\mathrm{AD}$ pathogenesis includes an intracellular pool (Gouras et al., 2000; D’Andrea et al., 2001; Gyure et al., 2001; Wirths et al., 2001; Busciglio et al., 2002; Mori et al., 2002;
Oddo et al., 2003; Sheng et al., 2003; Cataldo et al., 2004; Echeverria et al., 2004; Lord et al., 2006) for which increasing evidence suggests a pathogenetically significant role (Gouras et al., 2005; LaFerla et al., 2007). Accumulation of $\mathrm{A} \beta 42$ within distal neuritic compartments is associated with subcellular pathology, a greater accumulation associated with more severe pathology (Takahashi et al., 2002, 2004). Moreover, accumulation of intraneuronal $A \beta$ coincided with physiological and behavioral abnormalities in $\mathrm{AD}$ transgenic mouse models (Billings et al., 2005; Cruz et al., 2006; Knobloch et al., 2007). In the current study, we use established stimulation protocols to demonstrate reduction of intraneuronal $\mathrm{A} \beta$ on synaptic activation in primary neurons and hippocampal slices from APP mutant mice. Thus, synaptic activity increases extracellular $A \beta$ and decreases intracellular $\mathrm{A} \beta$. Given evidence for toxicity of both extracellular and intracellular $\mathrm{A} \beta$, it was not clear what the effect of synaptic activity would be on synaptic proteins. Increased extracellular $\mathrm{A} \beta$ was expected to damage synapses, and decreased intracellular $\mathrm{A} \beta$ to be protective. In fact, we found that synaptic activation in cultured $\mathrm{Tg} 2576$ neurons restored levels of the scaffold protein PSD-95 back to wild-type levels. These data indicate that synaptic activity could be protective against $\mathrm{A} \beta$-related synaptic changes, and suggest that the effect of synaptic activity on the intracellular pool of $\mathrm{A} \beta$ was of key importance. We cannot fully rule out the possibility that the effect of synaptic activity on PSD-95 levels occurred by a mechanism independent of $\mathrm{A} \beta$, but there was no effect of synaptic activity on PSD-95 levels in wild-type neurons.

As further evidence for an important role of intracellular $\mathrm{A} \beta$, it should be noted that the extracellular and intracellular pools of $\mathrm{A} \beta$ are tightly interconnected. For example, it was shown that addition of extracellular $A \beta 1-42$ to human embryonic kidney cells increased newly generated intracellular A $\beta 42$ (Yang et al., 1999). We now show that extracellular $A \beta 1-42$ increases $A \beta 42$ within neurons as well. The mechanism whereby extracellular $A \beta$ is toxic remains unclear, but may occur via intraneuronal $\mathrm{A} \beta$. Extracellular A $\beta 1-42$ caused cell death in wild-type neurons but not in APP knock-out neurons (Lorenzo et al., 2000) or in neuroblastoma cells harboring APP with point mutations in the NPXY motif (Shaked et al., 2006). We now provide the first data that levels of synaptic proteins that are decreased by extracellular A $\beta 1-42$ (Almeida et al., 2005; Snyder et al., 2005) are not altered when $A \beta 1-42$ is applied in the presence of $\gamma$-secretase inhibitor or in APP knock-out neurons. These data indicate that synaptotoxicity of $A \beta 1-42$ requires $\gamma$-secretase processing of APP. This supports a role for intraneuronal $\mathrm{A} \beta$, although we cannot rule out involvement of other APP cleavage products.

We demonstrate that synaptic activation affects APP transport and processing. Specifically, we provide evidence that synaptic activation promotes anterograde transport of APP in dendrites to syn- 
a

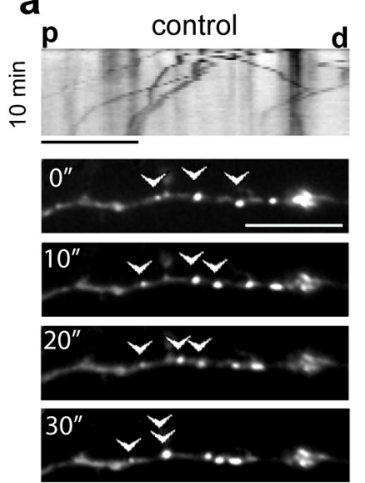

b

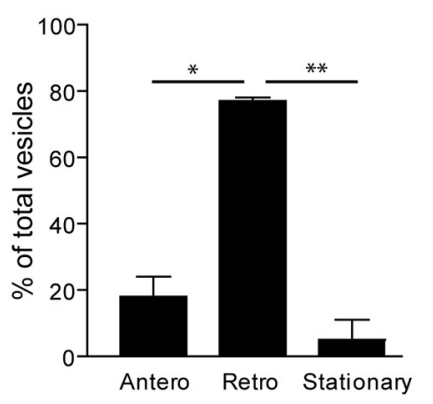

C

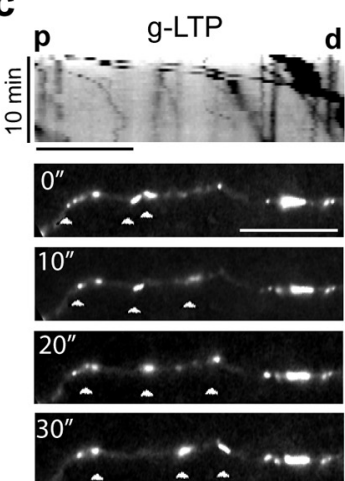

d

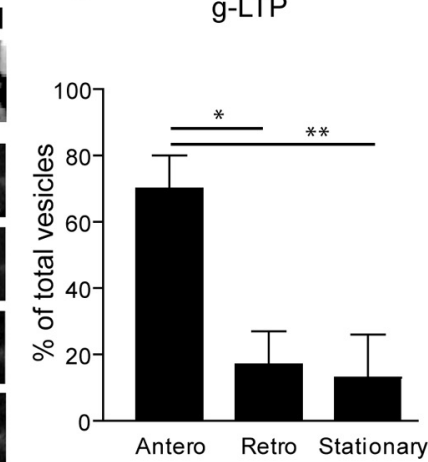

e
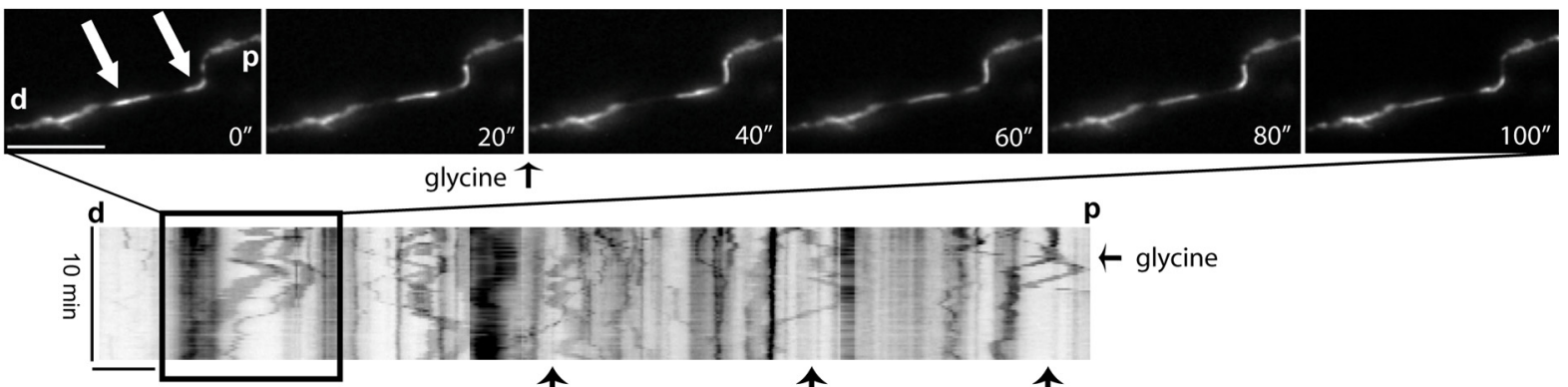

glycine $\uparrow$

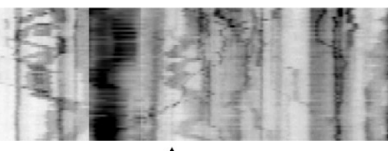

f

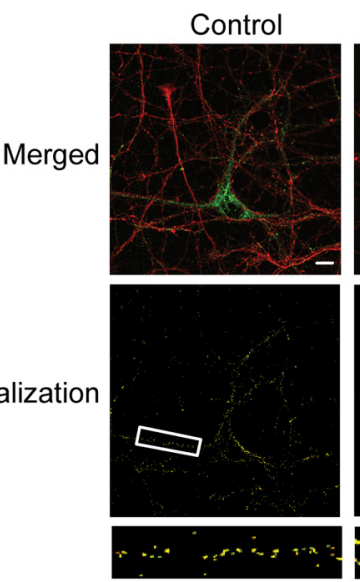

h

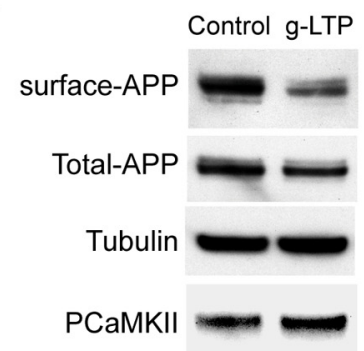

$\uparrow$

g-LTP
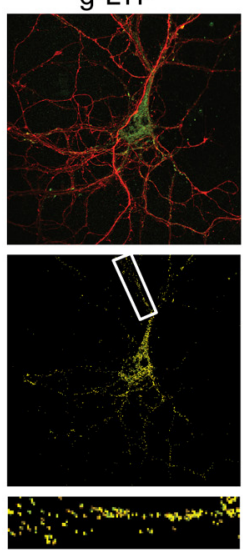

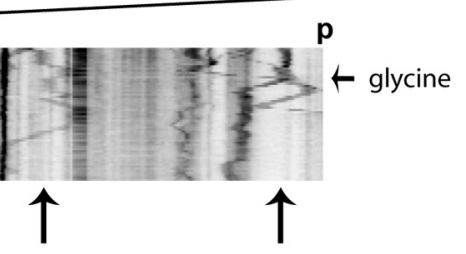

Colocalization
Merged

g

Control g-LTP

surface-APP

Total-APP

Tubulin

PCaMKII

i

No permeabilization
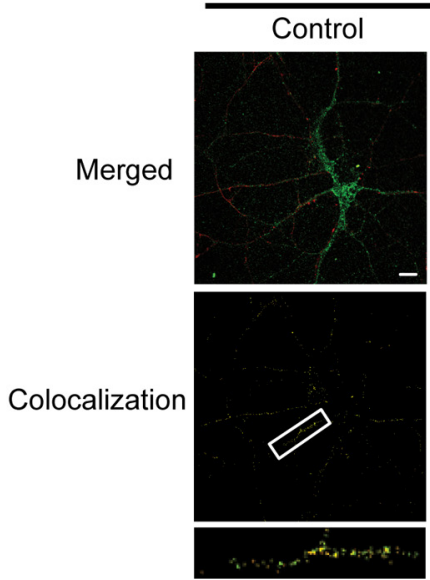
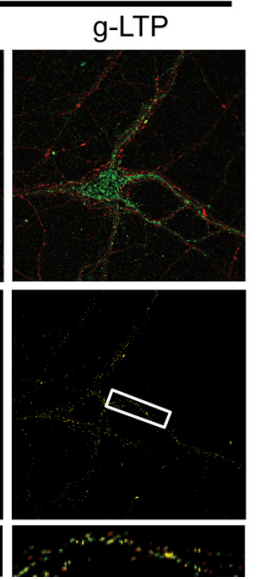

Figure 4. APP is transported to synapses with synaptic activity. $\boldsymbol{a}$, Live cell imaging of Tg2576 cultured neurons transfected with APP-YFP. At steady state, movement of APP-YFP in dendrites is principally retrograde in these experimental conditions (see Materials and Methods). Kymographic analysis of APP-YFP moving vesicles (upper panel). Images were acquired at $10 \mathrm{~s}$ intervals for a total of $10 \mathrm{~min}$. Arrowheads indicate movement of several APP-YFP containing vesicles. $\boldsymbol{b}$, Quantitation of anterograde, retrograde and stationary APP-YFP containing-vesicles trafficking at steady state $(n=3)$. c, Live cell imaging of Tg2576 neurons transfected with APP-YFP after g-LTP. At steady state, movement of APP-YFP in neurites is predominantly anterograde. Images were acquired at intervals of 10 s for a total of $10 \mathrm{~min}$. Arrowheads indicate movement of several APP-YFP containing vesicles. $\boldsymbol{d}$, Quantitation of anterograde, retrograde and stationary APP-YFP containing-vesicles trafficking in Tg2576 dendrites with glycine treatment $(n=3)$.e, Representative images of APP-YFP vesicles before and after infusion with glycine. Images are shown $20 \mathrm{~s}$ apart. For complete movie with 10 s intervals see supplemental Movie S3, available at www.jneurosci.org as supplemental material. White arrows indicate two APP-YFP-containing vesicles that reverse direction from retrograde to anterograde on infusion of glycine at 20 s. Live cell images of Tg2576 cultured neurons transfected with APP-YFP were acquired at 10 s intervals for a total of 10 min per movie. The small black arrows indicate the time when glycine was added. Large black arrows indicate several other examples of reversal from retrograde to anterograde movement of APP-YFP containing vesicles in (Figure legend continues.) 
a
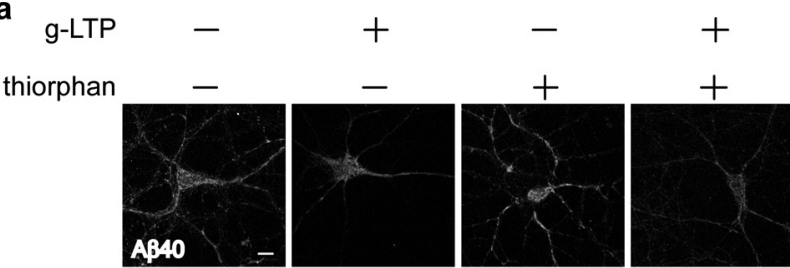

b
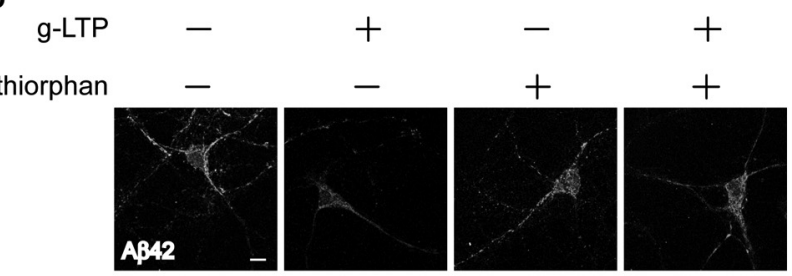

C
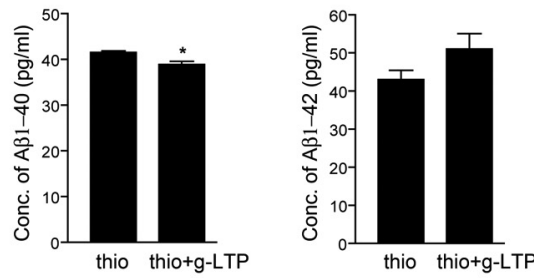

d

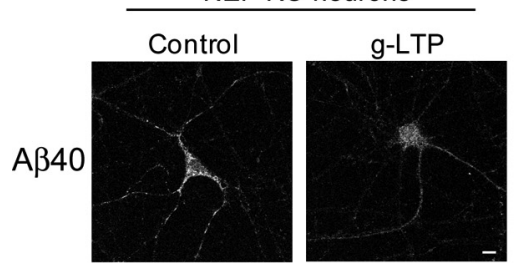

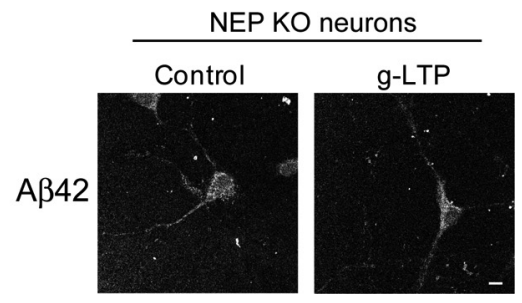

Figure 5. Involvement of neprilysin in $\mathrm{g}$-LTP induced reduction of intraneuronal A $\beta 42$. $\boldsymbol{a}$, Fluorescent immunolabeling of A $\beta 40$ in $\mathrm{g}$-LTP activated versus nonactivated Tg2576 neurons in the presence or absence of the neprilysin inhibitor thiorphan. Despite inhibition of neprilysin, $g$-LTP reduces intraneuronal $A \beta 40$ by $12 \pm 1 \%$ as demonstrated by confocal immunofluorescence $(n=3 ; p<0.01)$. $\boldsymbol{b}$, Fluorescent immunolabeling for $A \beta 42$ in $\mathrm{g}$-LTP activated versus nonactivated Tg2576 neurons in the presence or absence of the neprilysin inhibitor thiorphan. Inhibition of neprilysin prevents $\mathrm{g}$-LTP induced reduction of intraneuronal $A \beta 42$, as demonstrated by confocal immunofluorescence $(n=3) . c, A \beta 1-40$ and $A \beta 1-42$ concentrations measured by ELISA in neuron lysates from $\mathrm{g}$-LTP and controls in the presence of thiorphan. Inhibition of neprilysin allows for synaptic activity-induced reduction of $A \beta 1-40$ but not of $A \beta 1-42$ ( $n=3 ; p<0.05$ for $A \beta 1-40$ values). $\boldsymbol{d}, \mathrm{g}$-LTP activated NEP KO neurons and NEP KO control neurons. $g$-LTP induces reduction of intraneuronal $A \beta 40$ (left panels; $39 \pm 12 \%$ reduction; $n=6 ; p<0.01$ ) but not $A \beta 42$ (right panels; $n=6$ ) in NEP KO neurons, as determined by confocal immunofluorescence. Scale bars, $10 \mu \mathrm{m}$.

apses, internalization at synapses, and $\beta$-cleavage. Synaptic stimulation has not previously been shown to affect APP transport. The effect of synaptic activity on transport of protein cargoes appears to be selective. Synaptic activation promotes transport of the proteasome into dendritic spines (Bingol and Schuman,

\section{$\leftarrow$}

(Figure legend continued.) the kymograph. $\boldsymbol{f}$, APP localizes to synapses on activation with g-LTP. Representative immunofluorescence for APP (green) and synapsin I (red) in Tg2576 neurons (upper panels). The lower panels demonstrate the increased localization (yellow) of APP with synapsin I on $\mathbf{g}$-LTP. $\boldsymbol{g}$, Levels of surface APP, normalized to total APP, were increased $89 \pm 29 \%$ in g-LTP activated compared with control Tg2576 neurons, as measured by surface biotinylation followed by Western blot $(n=8, p<0.05)$. $\boldsymbol{h}$, Levels of surface APP, normalized to total APP, were reduced $33 \pm 2 \%$ in synaptosomal preparations of $g$-LTP activated compared with untreated $\mathrm{Tg} 2576$ neurons, as assayed by surface biotinylation followed by Western blot $(n=5 ; p<0.05)$. $\boldsymbol{i}$, Surface APP (green) and synapsin I (red) immunofluorescence in g-LTP activated compared with control Tg2576 neurons in the absence of permeabilization. Compared with Figure $4 f$ (done with permeabilization), lower panels reveal no increase in localization of surface APP with synapsin I on synaptic activity. d, Distal; $p$, proximal; scale bar, $10 \mu \mathrm{m}$.
2006) and transport of the syntabulinkinesin family 5B complex down axons (Cai et al., 2007). In contrast, synaptic activity anchors mitochondria at synapses (Kang et al., 2008), and glutamate receptor stimulation or inhibition does not affect dendritic transport of GluR1 and GluR2 (Perestenko and Henley, 2003). Increased APP transport and $\beta$-cleavage in response to synaptic activity supports an overall increase in $A \beta$ production at synapses with activity, consistent with the scenario proposed by Cirrito and colleagues (2008).

It was possible that the effects of synaptic activity on intracellular $A \beta$ were completely attributable to relocation of intracellular $\mathrm{A} \beta$ to the extracellular space. However, synaptic activity failed to reduce intraneuronal $A \beta 42$ in neurons treated with the neprilysin inhibitor thiorphan or in neprilysin knock-out neurons. These data implicate neprilysin in the reduction of intraneuronal $A \beta 42$ with synaptic activity. We note that $A \beta 42$ is the most pathogenic isoform of $A \beta$ and also is the predominant species that accumulates intraneuronally. In contrast, intraneuronal $A \beta 40$ was still decreased with synaptic activity in thiorphan-treated or neprilysin knock-out neurons. It was previously reported that neprilysin degrades $\mathrm{A} \beta 1-40$ and $\mathrm{A} \beta 1-42$ to a similar extent in vivo (Iwata et al., 2001), but when thiorphan was infused into the brain, only total levels of $A \beta 42$ but not $A \beta 40$ were elevated (Iwata et al., 2000; Belinson et al., 2008). These results are consistent with our data, which suggest that the activity-induced reduction in intraneuronal $\mathrm{A} \beta 42$ is primarily neprilysin-dependent, whereas that for $A \beta 40$ occurs by neprilysinindependent mechanisms, likely by secretion. $\mathrm{A} \beta 40$ is more soluble than $\mathrm{A} \beta 42$ and is secreted more efficiently. With synaptic activation, the secretion of both $\mathrm{A} \beta$ species was enhanced; however, the increase in $A \beta 40$ secretion was more pronounced than it was for $\mathrm{A} \beta 42$ in $\mathrm{Tg} 2576$ organotypic hippocampal slices (Kamenetz et al., 2003).

The mechanism whereby $\mathrm{A} \beta 42$ damages synapses is of major interest. Increasing evidence supports that $A \beta$ oligomers are the most toxic $A \beta$ species, and $A \beta$ oligomers do accumulate at synapses, both intracellularly (Takahashi et al., 2004) and extracellularly (Deshpande et al., 2009). The intracellular accumulation of $\mathrm{A} \beta 42$ oligomers is associated with early degeneration of distal neurites and synaptic compartments. We have therefore viewed the initiation of extracellular $A \beta$ deposition to be a result of intracellular $A \beta 42$ accumulation and oligomerization causing degeneration of distal neurites and synapses (Gouras et al., 2005).

The reduction of intraneuronal $\mathrm{A} \beta$ with synaptic activity supports the possibility that synaptic activity may be a protective factor in $\mathrm{AD}$ pathogenesis. Even with activity-induced secretion, the concentration of extracellular $A \beta$ remains in the picomolar range in our cultured neurons as well as brain interstitial fluid 
(Cirrito et al., 2003, 2005). At this concentration, extracellular A $\beta$ may be nontoxic. In fact, it was recently reported that picomolar concentrations of $A \beta$ could enhance LTP and memory (Puzzo et al., 2008; Garcia-Osta and Alberini, 2009), although this is controversial (Calabrese et al., 2007). We hypothesize that under normal conditions of synaptic activity, intracellular and secreted $\mathrm{A} \beta$ are efficiently cleared, but clearance mechanisms become impaired with aging. In fact, neprilysin has been reported to decline with aging (Iwata et al., 2002). Since neprilysin is localized to synapses (Fukami et al., 2002), its age-related decline could explain the synaptic accumulation of $A \beta 42$ that we have observed both in $\mathrm{AD}$ transgenic mice and human $\mathrm{AD}$ brains by immunoelectron microscopy (Takahashi et al., 2002, 2004, 2008). With progressive pathology, this accumulated intraneuronal $\mathrm{A} \beta 42$ could then be released to the extracellular space at high concentrations and become toxic to surrounding synapses.

\section{References}

Almeida CG, Tampellini D, Takahashi RH, Greengard P, Lin MT, Snyder EM, Gouras GK (2005) Beta-amyloid accumulation in APP mutant neurons reduces PSD-95 and GluR1 in synapses. Neurobiol Dis 20:187-198.

Almeida CG, Takahashi RH, Gouras GK (2006) Beta-amyloid accumulation impairs multivesicular body sorting by inhibiting the ubiquitinproteasome system. J Neurosci 26:4277-4288.

Ambrée O, Leimer U, Herring A, Görtz N, Sachser N, Heneka MT, Paulus W, Keyvani K (2006) Reduction of amyloid angiopathy and Abeta plaque burden after enriched housing in TgCRND8 mice: involvement of multiple pathways. Am J Pathol 169:544-552.

Belinson H, Lev D, Masliah E, Michaelson DM (2008) Activation of the amyloid cascade in apolipoprotein E4 transgenic mice induces lysosomal activation and neurodegeneration resulting in marked cognitive deficits. J Neurosci 28:4690-4701.

Billings LM, Oddo S, Green KN, McGaugh JL, LaFerla FM (2005) Intraneuronal Abeta causes the onset of early Alzheimer's disease-related cognitive deficits in transgenic mice. Neuron 45:675-688.

Bingol B, Schuman EM (2006) Activity-dependent dynamics and sequestration of proteasomes in dendritic spines. Nature 441:1144-1148.

Brody DL, Magnoni S, Schwetye KE, Spinner ML, Esparza TJ, Stocchetti N, Zipfel GJ, Holtzman DM (2008) Amyloid-beta dynamics correlate with neurological status in the injured human brain. Science 321:1221-1224.

Busciglio J, Pelsman A, Wong C, Pigino G, Yuan M, Mori H, Yankner BA (2002) Altered metabolism of the amyloid beta precursor protein is associated with mitochondrial dysfunction in Down's syndrome. Neuron 33:677-688.

Cai Q, Pan PY, Sheng ZH (2007) Syntabulin-kinesin-1 family member 5Bmediated axonal transport contributes to activity-dependent presynaptic assembly. J Neurosci 27:7284-7296.

Calabrese B, Shaked GM, Tabarean IV, Braga J, Koo EH, Halpain S (2007) Rapid, concurrent alterations in pre- and postsynaptic structure induced by naturally-secreted amyloid-beta protein. Mol Cell Neurosci 35:183-193

Casas C, Sergeant N, Itier JM, Blanchard V, Wirths O, van der Kolk N, Vingtdeux V, van de Steeg E, Ret G, Canton T, Drobecq H, Clark A, Bonici B, Delacourte A, Benavides J, Schmitz C, Tremp G, Bayer TA, Benoit P, Pradier L (2004) Massive CA1/2 neuronal loss with intraneuronal and $\mathrm{N}$-terminal truncated Abeta42 accumulation in a novel Alzheimer transgenic model. Am J Pathol 165:1289-1300.

Cataldo AM, Petanceska S, Terio NB, Peterhoff CM, Durham R, Mercken M, Mehta PD, Buxbaum J, Haroutunian V, Nixon RA (2004) Abeta localization in abnormal endosomes: association with earliest Abeta elevations in $\mathrm{AD}$ and Down syndrome. Neurobiol Aging 25:1263-1272.

Cirrito JR, May PC, O’Dell MA, Taylor JW, Parsadanian M, Cramer JW, Audia JE, Nissen JS, Bales KR, Paul SM, DeMattos RB, Holtzman DM (2003) In vivo assessment of brain interstitial fluid with microdialysis reveals plaque-associated changes in amyloid-beta metabolism and halflife. J Neurosci 23:8844-8853.

Cirrito JR, Yamada KA, Finn MB, Sloviter RS, Bales KR, May PC, Schoepp DD, Paul SM, Mennerick S, Holtzman DM (2005) Synaptic activity regulates interstitial fluid amyloid-beta levels in vivo. Neuron 48:913-922.

Cirrito JR, Kang JE, Lee J, Stewart FR, Verges DK, Silverio LM, Bu G, Men- nerick S, Holtzman DM (2008) Endocytosis is required for synaptic activity-dependent release of amyloid-beta in vivo. Neuron 58:42-51.

Coleman PD, Yao PJ (2003) Synaptic slaughter in Alzheimer's disease. Neurobiol Aging 24:1023-1027.

Cruz JC, Kim D, Moy LY, Dobbin MM, Sun X, Bronson RT, Tsai LH (2006) p25/cyclin-dependent kinase 5 induces production and intraneuronal accumulation of amyloid beta in vivo. J Neurosci 26:10536-10541.

D’Andrea MR, Nagele RG, Wang HY, Peterson PA, Lee DH (2001) Evidence that neurones accumulating amyloid can undergo lysis to form amyloid plaques in Alzheimer's disease. Histopathology 38:120-134.

DeKosky ST, Scheff SW (1990) Synapse loss in frontal cortex biopsies in Alzheimer's disease: correlation with cognitive severity. Ann Neurol 27:457-464.

Deshpande A, Kawai H, Metherate R, Glabe CG, Busciglio J (2009) A role for synaptic zinc in activity-dependent Abeta oligomer formation and accumulation at excitatory synapses. J Neurosci 29:4004-4015.

Echeverria V, Ducatenzeiler A, Dowd E, Jänne J, Grant SM, Szyf M, Wandosell F, Avila J, Grimm H, Dunnett SB, Hartmann T, Alhonen L, Cuello AC (2004) Altered mitogen-activated protein kinase signaling, tau hyperphosphorylation and mild spatial learning dysfunction in transgenic rats expressing the beta-amyloid peptide intracellularly in hippocampal and cortical neurons. Neuroscience 129:583-592.

Ehlers MD (2003) Activity level controls postsynaptic composition and signaling via the ubiquitin-proteasome system. Nat Neurosci 6:231-242.

Fukami S, Watanabe K, Iwata N, Haraoka J, Lu B, Gerard NP, Gerard C, Fraser P, Westaway D, St George-Hyslop P, Saido TC (2002) Abetadegrading endopeptidase, neprilysin, in mouse brain: synaptic and axonal localization inversely correlating with Abeta pathology. Neurosci Res 43:39-56.

Garcia-Osta A, Alberini CM (2009) Amyloid beta mediates memory formation. Learn Mem 16:267-272.

Gouras GK, Tsai J, Naslund J, Vincent B, Edgar M, Checler F, Greenfield JP, Haroutunian V, Buxbaum JD, Xu H, Greengard P, Relkin NR (2000) Intraneuronal Abeta42 accumulation in human brain. Am J Pathol 156:15-20.

Gouras GK, Almeida CG, Takahashi RH (2005) Intraneuronal Abeta accumulation and origin of plaques in Alzheimer's disease. Neurobiol Aging 26:1235-1244.

Gyure KA, Durham R, Stewart WF, Smialek JE, Troncoso JC (2001) Intraneuronal abeta-amyloid precedes development of amyloid plaques in Down syndrome. Arch Pathol Lab Med 125:489-492.

Haass C, Selkoe DJ (2007) Soluble protein oligomers in neurodegeneration: lessons from the Alzheimer's amyloid beta-peptide. Nat Rev Mol Cell Biol 8:101-112.

Hsiao K, Chapman P, Nilsen S, Eckman C, Harigaya Y, Younkin S, Yang F, Cole G (1996) Correlative memory deficits, Abeta elevation, and amyloid plaques in transgenic mice. Science 274:99-102.

Hsieh H, Boehm J, Sato C, Iwatsubo T, Tomita T, Sisodia S, Malinow R (2006) AMPAR removal underlies Abeta-induced synaptic depression and dendritic spine loss. Neuron 52:831-843.

Iwata N, Tsubuki S, Takaki Y, Watanabe K, Sekiguchi M, Hosoki E, Kawashima-Morishima M, Lee HJ, Hama E, Sekine-Aizawa Y, Saido TC (2000) Identification of the major Abeta1-42-degrading catabolic pathway in brain parenchyma: suppression leads to biochemical and pathological deposition. Nat Med 6:143-150.

Iwata N, Tsubuki S, Takaki Y, Shirotani K, Lu B, Gerard NP, Gerard C, Hama E, Lee HJ, Saido TC (2001) Metabolic regulation of brain Abeta by neprilysin. Science 292:1550-1552.

Iwata N, Takaki Y, Fukami S, Tsubuki S, Saido TC (2002) Region-specific reduction of A beta-degrading endopeptidase, neprilysin, in mouse hippocampus upon aging. J Neurosci Res 70:493-500.

Kaether C, Skehel P, Dotti CG (2000) Axonal membrane proteins are transported in distinct carriers: a two-color video microscopy study in cultured hippocampal neurons. Mol Biol Cell 11:1213-1224.

Kamenetz F, Tomita T, Hsieh H, Seabrook G, Borchelt D, Iwatsubo T, Sisodia S, Malinow R (2003) APP processing and synaptic function. Neuron 37:925-937.

Kang JS, Tian JH, Pan PY, Zald P, Li C, Deng C, Sheng ZH (2008) Docking of axonal mitochondria by syntaphilin controls their mobility and affects short-term facilitation. Cell 132:137-148.

Kienlen-Campard P, Miolet S, Tasiaux B, Octave JN (2002) Intracellular 
amyloid-beta 1-42, but not extracellular soluble amyloid-beta peptides, induces neuronal apoptosis. J Biol Chem 277:15666-15670.

Knobloch M, Konietzko U, Krebs DC, Nitsch RM (2007) Intracellular Abeta and cognitive deficits precede beta-amyloid deposition in transgenic arcAbeta mice. Neurobiol Aging 28:1297-1306.

Koo EH, Squazzo SL (1994) Evidence that production and release of amyloid beta-protein involves the endocytic pathway. J Biol Chem 269:17386-17389.

Lacor PN, Buniel MC, Chang L, Fernandez SJ, Gong Y, Viola KL, Lambert MP, Velasco PT, Bigio EH, Finch CE, Krafft GA, Klein WL (2004) Synaptic targeting by Alzheimer's-related amyloid beta oligomers. J Neurosci 24:10191-10200.

LaFerla FM, Green KN, Oddo S (2007) Intracellular amyloid-beta in Alzheimer's disease. Nat Rev Neurosci 8:499-509.

Lazarov O, Robinson J, Tang YP, Hairston IS, Korade-Mirnics Z, Lee VM, Hersh LB, Sapolsky RM, Mirnics K, Sisodia SS (2005) Environmental enrichment reduces Abeta levels and amyloid deposition in transgenic mice. Cell 120:701-713.

Li F, Calingasan NY, Yu F, Mauck WM, Toidze M, Almeida CG, Takahashi RH, Carlson GA, Flint Beal M, Lin MT, Gouras GK (2004) Increased plaque burden in brains of APP mutant MnSOD heterozygous knockout mice. J Neurochem 89:1308-1312.

Lord A, Kalimo H, Eckman C, Zhang XQ, Lannfelt L, Nilsson LN (2006) The Arctic Alzheimer mutation facilitates early intraneuronal Abeta aggregation and senile plaque formation in transgenic mice. Neurobiol Aging 27:67-77.

Lorenzo A, Yuan M, Zhang Z, Paganetti PA, Sturchler-Pierrat C, Staufenbiel M, Mautino J, Vigo FS, Sommer B, Yankner BA (2000) Amyloid beta interacts with the amyloid precursor protein: a potential toxic mechanism in Alzheimer's disease. Nat Neurosci 3:460-464.

Lu B, Gerard NP, Kolakowski LF Jr, Bozza M, Zurakowski D, Finco O, Carroll MC, Gerard C (1995) Neutral endopeptidase modulation of septic shock. J Exp Med 181:2271-2275.

Lu W, Man H, Ju W, Trimble WS, MacDonald JF, Wang YT (2001) Activation of synaptic NMDA receptors induces membrane insertion of new AMPA receptors and LTP in cultured hippocampal neurons. Neuron 29:243-254.

Magrané J, Rosen KM, Smith RC, Walsh K, Gouras GK, Querfurth HW (2005) Intraneuronal beta-amyloid expression downregulates the Akt survival pathway and blunts the stress response. J Neurosci 25:10960-10969.

Meyer-Luehmann M, Spires-Jones TL, Prada C, Garcia-Alloza M, de Calignon A, Rozkalne A, Koenigsknecht-Talboo J, Holtzman DM, Bacskai BJ, Hyman BT (2008) Rapid appearance and local toxicity of amyloid-beta plaques in a mouse model of Alzheimer's disease. Nature 451:720-724.

Mori C, Spooner ET, Wisniewsk KE, Wisniewski TM, Yamaguch H, Saido TC, Tolan DR, Selkoe DJ, Lemere CA (2002) Intraneuronal Abeta42 accumulation in Down syndrome brain. Amyloid 9:88-102.

Oddo S, Caccamo A, Shepherd JD, Murphy MP, Golde TE, Kayed R, Metherate R, Mattson MP, Akbari Y, LaFerla FM (2003) Triple-transgenic model of Alzheimer's disease with plaques and tangles: intracellular Abeta and synaptic dysfunction. Neuron 39:409-421.

Oddo S, Billings L, Kesslak JP, Cribbs DH, LaFerla FM (2004) Abeta immunotherapy leads to clearance of early, but not late, hyperphosphorylated tau aggregates via the proteasome. Neuron 43:321-332.

Oddo S, Caccamo A, Smith IF, Green KN, LaFerla FM (2006) A dynamic relationship between intracellular and extracellular pools of Abeta. Am J Pathol 168:184-194.

Palop JJ, Chin J, Mucke L (2006) A network dysfunction perspective on neurodegenerative diseases. Nature 443:768-773.

Palop JJ, Chin J, Roberson ED, Wang J, Thwin MT, Bien-Ly N, Yoo J, Ho KO, Yu GQ, Kreitzer A, Finkbeiner S, Noebels JL, Mucke L (2007) Aberrant excitatory neuronal activity and compensatory remodeling of inhibitory hippocampal circuits in mouse models of Alzheimer's disease. Neuron 55:697-711

Perestenko PV, Henley JM (2003) Characterization of the intracellular transport of GluR1 and GluR2 alpha-amino-3-hydroxy-5-methyl-4isoxazole propionic acid receptor subunits in hippocampal neurons. J Biol Chem 278:43525-43532.
Puzzo D, Privitera L, Leznik E, Fà M, Staniszewski A, Palmeri A, Arancio O (2008) Picomolar amyloid-beta positively modulates synaptic plasticity and memory in hippocampus. J Neurosci 28:14537-14545.

Rajendran L, Schneider A, Schlechtingen G, Weidlich S, Ries J, Braxmeier T, Schwille P, Schulz JB, Schroeder C, Simons M, Jennings G, Knölker HJ, Simons K (2008) Efficient inhibition of the Alzheimer's disease betasecretase by membrane targeting. Science 320:520-523.

Runz H, Rietdorf J, Tomic I, de Bernard M, Beyreuther K, Pepperkok R, Hartmann T (2002) Inhibition of intracellular cholesterol transport alters presenilin localization and amyloid precursor protein processing in neuronal cells. J Neurosci 22:1679-1689.

Selkoe DJ (2002) Alzheimer's disease is a synaptic failure. Science 298:789-791.

Shaked GM, Kummer MP, Lu DC, Galvan V, Bredesen DE, Koo EH (2006) Abeta induces cell death by direct interaction with its cognate extracellular domain on APP (APP 597-624). FASEB J 20:1254-1256.

Shankar GM, Li S, Mehta TH, Garcia-Munoz A, Shepardson NE, Smith I, Brett FM, Farrell MA, Rowan MJ, Lemere CA, Regan CM, Walsh DM, Sabatini BL, Selkoe DJ (2008) Amyloid-beta protein dimers isolated directly from Alzheimer's brains impair synaptic plasticity and memory. Nat Med 14:837-842.

Sheng JG, Bora SH, Xu G, Borchelt DR, Price DL, Koliatsos VE (2003) Lipopolysaccharide-induced-neuroinflammation increases intracellular accumulation of amyloid precursor protein and amyloid beta peptide in APPswe transgenic mice. Neurobiol Dis 14:133-145.

Snyder EM, Nong Y, Almeida CG, Paul S, Moran T, Choi EY, Nairn AC, Salter MW, Lombroso PJ, Gouras GK, Greengard P (2005) Regulation of NMDA receptor trafficking by amyloid-beta. Nat Neurosci 8:1051-1058.

Stern Y (2006) Cognitive reserve and Alzheimer disease. Alzheimer Dis Assoc Disord 20:S69-74

Takahashi RH, Almeida CG, Kearney PF, Yu F, Lin MT, Milner TA, Gouras GK (2004) Oligomerization of Alzheimer's beta-amyloid within processes and synapses of cultured neurons and brain. J Neurosci 24:3592-3599.

Takahashi RH, Milner TA, Li F, Nam EE, Edgar MA, Yamaguchi H, Beal MF, Xu H, Greengard P, Gouras GK (2002) Intraneuronal Alzheimer abeta42 accumulates in multivesicular bodies and is associated with synaptic pathology. Am J Pathol 161:1869-1879.

Takahashi RH, Capetillo-Zarate E, Lin MT, Milner TA, Gouras GK (2008) Co-occurrence of Alzheimer's disease beta-amyloid and tau pathologies at synapses. Neurobiol Aging. Advance online publication. Retrieved May 14, 2009. doi:10.1016/j.neurobiolaging.2008.07.021.

Tampellini D, Magrané J, Takahashi RH, Li F, Lin MT, Almeida CG, Gouras GK (2007) Internalized antibodies to the Abeta domain of APP reduce neuronal Abeta and protect against synaptic alterations. J Biol Chem 282:18895-18906.

Terry RD, Masliah E, Salmon DP, Butters N, DeTeresa R, Hill R, Hansen LA, Katzman R (1991) Physical basis of cognitive alterations in Alzheimer's disease: synapse loss is the major correlate of cognitive impairment. Ann Neurol 30:572-580.

Wang Z, Edwards JG, Riley N, Provance DW Jr, Karcher R, Li XD, Davison IG, Ikebe M, Mercer JA, Kauer JA, Ehlers MD (2008) Myosin Vb mobilizes recycling endosomes and AMPA receptors for postsynaptic plasticity. Cell 135:535-548.

Wirths O, Multhaup G, Czech C, Blanchard V, Moussaoui S, Tremp G, Pradier L, Beyreuther K, Bayer TA (2001) Intraneuronal Abeta accumulation precedes plaque formation in beta-amyloid precursor protein and presenilin-1 double-transgenic mice. Neurosci Lett 306:116-120.

Wong-Riley MT, Welt C (1980) Histochemical changes in cytochrome oxidase of cortical barrels after vibrissal removal in neonatal and adult mice. Proc Natl Acad Sci U S A 77:2333-2337.

Yang AJ, Chandswangbhuvana D, Shu T, Henschen A, Glabe CG (1999) Intracellular accumulation of insoluble, newly synthesized abetan- 42 in amyloid precursor protein-transfected cells that have been treated with Abeta1-42. J Biol Chem 274:20650-20656.

Zhang Y, McLaughlin R, Goodyer C, LeBlanc A (2002) Selective cytotoxicity of intracellular amyloid beta peptide1-42 through p53 and Bax in cultured primary human neurons. J Cell Biol 156:519-529. 